\title{
Genetic Diversity Analysis in Chilli (Capsicum annuum L.) Found in Manipur Using RAPD Markers
}

\author{
Atom Annupama Devi ${ }^{1 *}$, Naorem Brajendra ${ }^{2}$ and Mutum Dinachandra ${ }^{3}$ \\ ${ }^{1}$ Department of Plant Molecular Genetics and Genomics, Institute of Bioresources and \\ Sustainable Development, Takyel, Manipur, India \\ ${ }^{2}$ Department of Genetics and Plant Breeding, Central Agricultural University, CAU, \\ Imphal, India \\ ${ }^{3}$ Department of Horticulture, Central Agricultural University, CAU, Imphal, India \\ *Corresponding author
}

\begin{abstract}
A B S T R A C T
Key words

Genetic diversity,

Manipur, polymorphic,

RAPD, Polymorphic

information content

Article Info

Accepted: 04 September 2018 Available Online:

10 October 2018

The present study was undertaken to understand the genetic diversity of Chilli found in Manipur using RAPD primers. Twenty (20) primers were screened, out of which 9 primers gave polymorphic bands which were used for further analysis. The polymorphic information content (PIC) values ranged from 0.2 (OPB-15) to 0.45 (OPW-04) with an average of 0.35 . The resolving power was found highest in OPW04 with value of 7.44 and lowest in OPA11 (2.10). Overall, it was found that OPW04 is a good primer which produced $100 \%$ polymorphism with high discriminating power. Cluster analysis using Unweighted Pair Group Method with Arithmetic Averages (UPGMA) grouped all the chilli samples into three major clusters at a distance coefficient of 0.50 , major cluster 1 consist of 4 cultivars (CAU 1, CAU 4, CAU 9, CAU 10). The $2^{\text {nd }}$ major clusters consist of 6 cultivars- (CAU 2, CAU 5, CAU 7, CAU 6, CAU 8, CAU 3. The $3^{\text {rd }}$ major cluster consist of only 1 cultivar (CAU 11). The results showed that RAPD can be effectively used to analysed genetic diversity of chilli found in Manipur.
\end{abstract}

\section{Introduction}

Chilli (capsicum sp.) belongs to solanaceae family, originated in Mexico, with secondary centres in Guatemala and Bulgaria (Salvador, 2002). Columbus introduced chilli in India in $15^{\text {th }}$ century (Basu and Krishna, 2003). Now, India is the world's largest producer, consumer and exporter of chillies. India is the largest producer of chillies with a total production of 26,804,941 tonnes (FAOSTAT, 2015). Several interspecific hybrids/derivatives of chilli originated in North-east, India (Daliwal, 2014). Chilli cultivars in India are famous for its pungency (hotness) and colour. Bhut jolokia, cultivated in Assam is the world's hottest chilli pepper (Bosland and Baral, 2007).

Characterization using morphological markers have been successfully used in different plants (Cong-Ying Yuan et al., 2015; Fang et al., 2017; Warnakula et al., 2017) but due to environmental factors, it suffer certain 
limitations. So, the molecular markers proven to be more effective than morphological and biochemical markers. RAPD are useful markers as it does not need of prior knowledge about the genome (Williams et al., 1990). RAPD markers have been successfully used in genetic diversity studies of chilli (Makari et al., 2009; Peeraullee et al., 2013; Mullianathan et al., 2014; Ferniah et al., 2018; Lalduhzuala et al., 2018).

\section{Materials and Methods}

\section{Plant Material}

In the present study, seeds from 11 (eleven) chilli cultivars were procured which was maintained at germplasm of CAU (Central agricultural university) Imphal. Details of chillis given in Table 1 . The seeds were thoroughly rinsed with distilled water, allowed to germinate using paper towel method and transplanted to small pot after 10 days.

\section{Genomic DNA}

The genomic DNA was extracted from leaf tissues of 20 days old young chilli plant using modified CTAB method (Doyle and Doyle, 1990). The leaves were grounded in 600uL extraction buffer (1M Tris $\mathrm{HCl}, \mathrm{pH} 8.0 ; 5 \mathrm{M}$ $\mathrm{NaCl} ; 0.5 \mathrm{M}$ EDTA; $10 \%$ SDS) and the mixture was treated with $5 \mu \mathrm{L}$ of Proteinase $\mathrm{K}$ $(20 \mathrm{mg} / \mathrm{mL})$ for $1 \mathrm{~h}$ at $36^{\circ} \mathrm{C}$. To this cell lysate, $500 \mu \mathrm{L}$ of CTAB buffer (10\% CTAB; 1M Tris $\mathrm{HCl} \mathrm{pH}$ 8.0; 0.5M EDTA; 5M NaCl; 5\% PVP was added and incubated for $2 \mathrm{~h}$ at $65^{\circ} \mathrm{C}$. The suspension was extracted thrice with equal volume of phenol: chloroform: isoamyl alcohol (24: 25:1). The DNA was precipitated using isopropanol, $3 \mathrm{M}$ sodium acetate and $70 \%$ ethanol, $10 \mu \mathrm{L}$ RNase $(10 \mu \mathrm{g} / \mathrm{mL})$ was added to each $50 \mu \mathrm{L}$ DNA and incubated for $30 \mathrm{~m}$ at $37^{\circ} \mathrm{C}$. DNA quantification was carried out using UV spectrophotometer (Cary 60 UV-Vis, Agilent Technology) by measuring the DNA concentration at $260 \mathrm{~nm}$ and 280 nm. Purity of DNA was determined by calculating the ratios of absorbance at ratios $260 \mathrm{~nm}$ to that of $280 \mathrm{~nm}$. The isolated DNA were run on $0.8 \%$ agarose gel electrophoresis to check the quality of DNA along with DNA ladder and photographed using gel documentation system (Biorad universal hood, USA).

\section{RAPD-PCR amplification}

A total of 20 decamer primers were initially screened, out of which 9 primers showed clear and polymorphic bands. RAPD-PCR was carried out in $25 \mu \mathrm{L}$ containing $50 \mathrm{ng}$ of genomic DNA, $2.5 \mathrm{mM} \mathrm{MgCl}_{2}, 0.5 \mathrm{mM}$ dNTP mix, $2.5 \mathrm{mM}$ buffer, 1UTaq polymerase and 10 pmol of each primer with the cycling condition at $94^{\circ} \mathrm{C}$ for $4 \mathrm{~m}$, followed by 40 cycles of $94^{\circ} \mathrm{C}$ for $1 \mathrm{~m}, 36^{\circ} \mathrm{C}$ for $45 \mathrm{~s}$ and $72^{\circ} \mathrm{C}$ for $2 \mathrm{~m}$ and final extension of $72^{\circ} \mathrm{C}$ for $7 \mathrm{~m}$. Amplified PCR products were separated by electrophoresis along with 100bp DNA ladder on a $1.8 \%$ agarose gel prepared in $1 \mathrm{X}$ TAE buffer.

\section{Scoring and PCR analysis}

Photographed Gel was scored as a binary matrix, where 1 represent band present and 0 represent band absent and dendrogram for cluster analysis using UPGMA (Unweighted Pair group Method with Arithmetic average) and genetic similarity matrix using NTSYS pc version 2.02 (Rohlf, 1998) software were generated. Polymorphism information content $\left(\mathrm{PIC}_{i}\right)$ of a band was calculated according to Anderson et al., (1993) as follow:

$$
\mathrm{PIC}_{i}=1-\sum_{j} \mathrm{f}_{i j}^{2}
$$

Where $\mathrm{f}_{i j}$ is the frequency of the $j^{\text {th }}$ pattern of the $i^{\text {th }}$ band. 
Resolving power (Rp) was calculated according to Prevost and Wilkinson, 1999 formula

$$
\mathrm{RP}=\sum_{i=1}^{n} \mathrm{IB}_{i}
$$

Where Informativeness of a band $\left(\mathrm{BI}_{i}\right)$ was calculated as:

$\mathrm{BI}_{i}=1-(2 \mathrm{X}|0.5-p|)$ where $p$ is the proportion of all accessions containing the band.

\section{Results and Discussion}

A total of 20 RAPD primers were initially screened for their amplification, out of which only 9 primers (OPA11, OPB-01, OPC03, OPB11, OPW04, OPB-15, OPC03, OPL05 and OPD13) produced a clear and reproducible banding pattern in all the samples. A total of 76 bands were produced from 9 RAPD primers, out of which 60 were polymorphic $(78.9 \%)$. The average band per primer was 8.4. The PIC values range from 0.28 (OPB-15) to 0.45 (OPW04). The percent polymorphism ranged from $70 \%$ (OPCOB) to $100 \%$ (OPW04). The resolving power was found highest in OPW04 with value of 7.44 and lowest in OPA11 (2.10). Overall, it was found that OPW04 is a good primer which produced $100 \%$ polymorphism with high discriminating power (Table 2). The amplification using RAPD primer (OPB 11) is shown in Figure 1.

The similarity data generated by NTSYS-pc version 2.02 (Rohlf, 1998) using simple matching matrix showed the highest similarity value (0.85) found between cultivars (CAU 5 - CAU 7), (CAU 6 -CAU 7) and (CAU 9 CAU 10). And the lowest value of 0.5 , found in cultivars (CAU 1 -CAU 11) (Table 3).

At a distance coefficient of 0.55 , the dendrogram divided 11 cultivars in three major cluster (Fig. 2). Major cluster 1 consist of 4 cultivars (CAU 1, CAU 4, CAU 9, CAU 10). The $2^{\text {nd }}$ major cluster consist of 6 cultivars- (CAU 2, CAU 5, CAU 7, CAU 6, CAU 8, CAU 3. The $3^{\text {rd }}$ major cluster consist of only 1 cultivar (CAU 11).

The dendrogram, is again divied into 5 major groups at a distance coefficient of 0.30 . Group I consist of 4 cultivars - (CAU 1, CAU 4, CAU 9 and CAU 10). Group II consist of 1 cultivar (CAU 2), Group III consist of 4 cultivars (CAU 5, CAU 7, CAU 6, CAU 8), Group IV consist of only 1 cultivar (CAU 3) and the last Group V consist of cultivar CAU 11.

Fig.1 RAPD gel profile of 11 chilli cultivars using OPB-11 primer

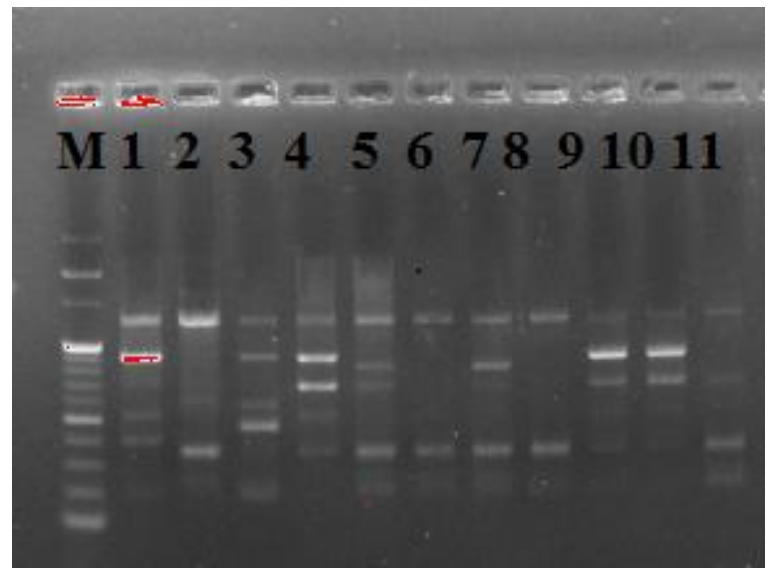


Fig.2 Dendrogram obtained from 11 chilli cultivars using RAPD data

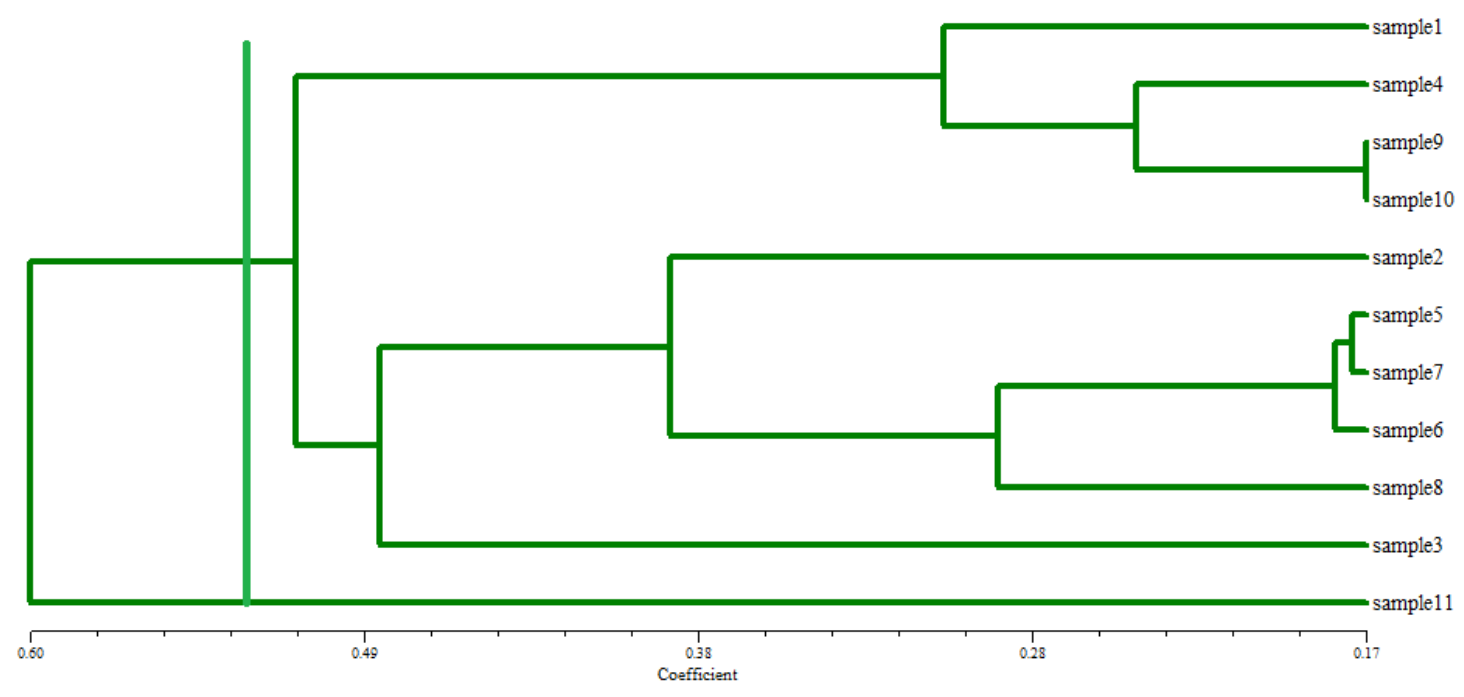

Table.1 Details of 11 chilli samples used in present studies

\begin{tabular}{|l|l|l|l|}
\hline Sl.no. & Vourcher no. & Cultivars & Source \\
\hline 1. & CAU-1 & Crispy long chilli & Central agricultural university germplasm, Imphal \\
\hline 2. & CAU-2 & Morok Asangbi & Central agricultural university germplasm, Imphal \\
\hline 3. & CAU-3 & Colour xanadu & Central agricultural university germplasm, Imphal \\
\hline 4. & CAU-4 & Meitei morok asabi & Central agricultural university germplasm, Imphal \\
\hline 5. & CAU-5 & Yensang morok & Central agricultural university germplasm, Imphal \\
\hline 6. & CAU-6 & Morok macha & Central agricultural university germplasm, Imphal \\
\hline 7. & CAU-7 & Churachandpur morok & Central agricultural university germplasm, Imphal \\
\hline 8. & CAU-8 & Fireball & Central agricultural university germplasm, Imphal \\
\hline 9. & CAU-9 & Meitei morok & Central agricultural university germplasm, Imphal \\
\hline 10. & CAU-10 & Meitei morok macha & Central agricultural university germplasm, Imphal \\
\hline 11. & CAU-11 & Xanadu & Central agricultural university germplasm, Imphal \\
\hline
\end{tabular}

Table.2 Details of RAPD -PCR amplification obtained from 11 chilli cultivars

\begin{tabular}{|c|c|c|c|c|c|c|c|c|}
\hline Sl.no. & $\begin{array}{l}\text { Primer } \\
\text { name }\end{array}$ & Primer sequence $\left(5^{\prime}-3^{\prime}\right)$ & $\begin{array}{l}\text { Total } \\
\text { band }\end{array}$ & PMB & MMB & $\% \mathbf{P M}$ & PIC & $\begin{array}{l}\text { Resolving } \\
\text { power }\end{array}$ \\
\hline 1. & OPA11 & CAA TCG CCG T & 10 & 9 & 1 & 90 & 0.31 & 2.10 \\
\hline 2. & OPB-01 & GTTTCGCTCC & 7 & 6 & 1 & 85.7 & 0.4 & 4.52 \\
\hline 3. & OPC03 & GGGGGTCTTT & 9 & 5 & 4 & 55.5 & 0.36 & 6.22 \\
\hline 4. & OPB11 & GTAGACCCGT & 9 & 7 & 2 & 77.7 & 0.4 & 6.9 \\
\hline 5. & OPW04 & CAGAAGCGGA & 7 & 7 & 0 & 100 & 0.45 & 7.44 \\
\hline 6 & OPB-15 & GGAGGGTGTT & 5 & 4 & 1 & 80 & 0.28 & 4.36 \\
\hline 7 & $\mathrm{OPC} 03$ & GGGGGTCTTT & 10 & 7 & 3 & 70 & 0.31 & 5.48 \\
\hline 8 & OPL05 & ACGCAGGCAC & 10 & 8 & 2 & 80 & 0.34 & 3.86 \\
\hline \multirow[t]{2}{*}{9} & OPD13 & GGGGTGACGA & 9 & 7 & 2 & 77.7 & 0.32 & 3.7 \\
\hline & & & 76 & 60 & & 78.9 & & \\
\hline
\end{tabular}

PMB - Polymorphic band; \%PM - Percentage of polymorphic band; PIC- Polymorphic information content; MMBMonomorphic band; $\mathrm{Rp}-$ Resolving power. 
Table.3 Simple matching (SM) matrix using RAPD data from 11 chilli cultivars

\begin{tabular}{|c|c|c|c|c|c|c|c|c|c|c|c|}
\hline & CAU-1 & CAU-2 & CAU-3 & CAU-4 & CAU-5 & CAU-6 & CAU-7 & CAU-8 & CAU-9 & CAU-10 & CAU-11 \\
\hline CAU-1 & 1.00 & & & & & & & & & & \\
\hline CAU-2 & 0.65 & 1.00 & & & & & & & & & \\
\hline CAU-3 & 0.52 & 0.63 & 1.00 & & & & & & & & \\
\hline $\mathrm{CAU}-4$ & 0.80 & 0.69 & 0.58 & 1.00 & & & & & & & \\
\hline CAU-5 & 0.62 & 0.68 & 0.55 & 0.61 & 1.00 & & & & & & \\
\hline CAU-6 & 0.55 & 0.77 & 0.60 & 0.63 & 0.83 & 1.00 & & & & & \\
\hline CAU-7 & 0.61 & 0.76 & 0.61 & 0.64 & 0.85 & 0.85 & 1.00 & & & & \\
\hline $\mathrm{CAU}-8$ & 0.51 & 0.62 & 0.58 & 0.60 & 0.75 & 0.82 & 0.71 & 1.00 & & & \\
\hline CAU-9 & 0.71 & 0.61 & 0.52 & 0.77 & 0.62 & 0.62 & 0.58 & 0.65 & 1.00 & & \\
\hline CAU-10 & 0.73 & 0.67 & 0.58 & 0.81 & 0.58 & 0.63 & 0.67 & 0.60 & 0.85 & 1.00 & \\
\hline CAU-11 & 0.50 & 0.61 & 0.50 & 0.58 & 0.67 & 0.64 & 0.63 & 0.73 & 0.57 & 0.54 & 1.00 \\
\hline
\end{tabular}

From this dendogram, we can conclude that, among 11 cultivars, the cultivar which is closely related is cultivars (CAU 9 and CAU 10) and the most diverse one is CAU 3 and CAU 11.

This finding supports molecular genetic diversity analysis using RAPD primers correlates with the morphological finding of Atom et al., (2017).

In conclusion, the RAPD primers used in this study are still efficient marker for successful identification and diversity studies of chilli.

\section{Acknowledgements}

The authors are thankful to DBT for the DBTRA fellowship (2015-2017) and also express gratitude to Department of genetics and plant breeding, CAU, Imphal for lab facility.

\section{References}

Andersson, J.A. Churchill, G.A. Autrique, J.E. Tanksley, S.D. and Sorrells, M.E., 1993, Optimizing parental selection for genetic-linkage maps. Genome., 36(1): 181-186

Atom, A. D. Brajendra, N. S. and Dinachandra, M. S., 2017, Classification and characterization of chilli (Capsicum annuum L.) found in Manipur using multivariate analysis. Electron. J. Plant. Breed., 8(1): 324330.

Bosland, P.W. and Baral, J.B., 2007, Bhut Jolokia-The world's hottest known chile pepper is a putative naturally occurring interspecific hybrid. Hortic. Sci. 42 (2): 222-224.

Bosland, P.W., 1996, Capsicums: Innovative uses of an ancient crop, in: Progress in new crops. (ASHS Press, Arlington), 479-487.

Colney, L., Wricha T., and Mayank, R., 2018, Morphological and molecular characterization of two distinct chilli cultivars from North Eastern India with special reference to pungency related genes. Sci. Hort., 240(20), 1-10.

Cong-Ying, Y. Ping, W. Pang-Pang, C. WenJun, X. Cheng, Z, Shuai. H, Ping, Z, Hong-Ping. Chang. Zhuang, H, Rong, H, Xiu-Tao, L, Jia-Zhuo, Ye and XinHong, Guo., 2015, Genetic diversity revealed by morphological traits and ISSR markers in 48 Okras (Abelmoschus escullentus L.). Physiol. Mol. Biol. Plants., 21(3): 359-364.

Dhaliwal, M. S. Naveen, G. Jindal, S. K., and Cheema, D. S., 2014, Heterosis in chilli (Capsicum annuum L.) using genetic 
male sterility. J. Res. Punjab. Agric. Univ (3 \& 4): 255-261.

Doyle, J.J. and Doyle, J.L., 1990, Isolation of plant DNA from fresh tissue. Focus., 12:13-15.

Ferniah, R., Kusdiyantini, E.and Nurhayati, N., 2018, Phylogenetic of Ornamented Chilli Based on the Fruit Morphology and Molecular Marker using OPA-12 Primer. Agric, 30(1), 57-62.

Makari, H. K. Ravikumar Patil H. S. Abhilash M., and Mohan Kumar H. D., 2009, Genetic diversity in commercial varieties of chilli as revealed by RAPD method. Indian. J. Sci. Technol., 2:4.

Mullainathan, L. Sridevi, A. Umavathi, Sanjai Gandhi, E.., 2014,Genetic variation in Mutants of chilli (Capsicum annum) revealed by RAPD marker, International letters of Natural Sciences, 11:1-8.
Peeraullee, N. and V.M. RanghooSanmukhiya, 2013. Assessment of genetic diversity in local chilli (Capsicum annuum) varieties in Mauritius. Int. J. Agric. Biol., 15: 891896.

Prevost, A. and Wilkinson, M.J., 1999, A new system of comparing PCR primers applied to ISSR fingerprinting of potato accessions. Theor. Appl. Genet., 98:107-112.

Rohlf, F.J., 1993, NTSYS-pc. Numerical taxonomy and multivariate analysis system. Exeter Software, New York.

Williams, G. K. Kubelik, A. R. Livak, K. L. Rafalshi, J. A. and Tingey, S. V., 1990, DNA polymorphisms amplified by arbitrary primers are useful as genetic markers. Nucleic Acids Res., 18:65316535.

\section{How to cite this article:}

Atom Annupama Devi, Naorem Brajendra and Mutum Dinachandra. 2018. Genetic Diversity Analysis in Chilli (Capsicum annuum L.) Found in Manipur Using RAPD Markers. Int.J.Curr.Microbiol.App.Sci. 7(10): 257-262. doi: https://doi.org/10.20546/ijcmas.2018.710.027 